\title{
Groundwater effects on diversity and abundance of lagoonal seagrasses in Kenya and on Zanzibar Island (East Africa)
}

\author{
Pauline Kamermans ${ }^{1, *}$, Marten A. Hemminga ${ }^{1}$, Jurgen F. Tack ${ }^{2}$, Miguel A. Mateo ${ }^{1}$, \\ Núria Marbà ${ }^{1}$, Matern Mtolera ${ }^{3}$, Johan Stapel ${ }^{1}$, Anouk Verheyden ${ }^{2}$, Toon Van Daele ${ }^{4}$ \\ ${ }^{1}$ Netherlands Institute of Ecology, Centre for Estuarine and Coastal Ecology, PO Box 140, 4400 AC Yerseke, The Netherlands \\ ${ }^{2}$ Fund for Scientific Research Flanders, c/o Free University, Institute of Environmental Research, Pleinlaan 2, \\ 1050 Brussels, Belgium \\ ${ }^{3}$ Institute of Marine Sciences, University of Dar es Salaam, PO Box 668, Zanzibar, Tanzania \\ ${ }^{4}$ Free University, Hydrology Department, Pleinlaan 2, 1050 Brussels, Belgium
}

\begin{abstract}
Seagrass species diversity and abundance were studied in East African back-reef lagoons with contrasting groundwater-outflow rates. The selection of the lagoons was based on a groundwater flow model. A total of 10 seagrass species was observed at all sites together. Sites with a higher groundwater outflow displayed a lower species diversity than sites with a lower groundwater outflow. Thalassodendron ciliatum dominated at sites with high groundwater outflow rates, while Thalassia hemprichii showed higher coverage at sites with low groundwater outflow. Porewater salinities were up to 5 psu lower at locations with predicted high groundwater-outflow rates indicating supply of freshwater. The reduction in porewater salinity at groundwater outflow sites is relatively low, which makes it unlikely that a difference in optimum salinity for growth is the main factor causing reduced diversity at these sites. Nitrogen-stable isotope signatures of seagrass leaves showed a significant increase with increased groundwater outflow rates. This suggests that the nitrogen source for these plants was, at least in part, groundwater. Differences in competition for nitrogen may explain the observed pattern in species diversity and abundance. To establish a substantive link between the observed reduced seagrass diversity or enhanced $\delta^{15} \mathrm{~N}$ values of $T$. ciliatum leaves on the one hand and increased groundwater outflow rates on the other, further exploration through detailed measurements of groundwater outflow rates and groundwater nitrogen isotopic composition are needed.
\end{abstract}

KEY WORDS: Groundwater model · Tropical seagrasses · Abundance · Diversity · Thalassia hemprichii $\cdot$ Thalassodendron ciliatum $\cdot$ Nitrogen $\cdot$ Salinity

Resale or republication not permitted without written consent of the publisher

\section{INTRODUCTION}

Submarine groundwater discharge is a widespread phenomenon throughout the world (Johannes 1980). The outflow in coastal areas is driven by the elevation

${ }^{*}$ Present address: Netherlands Institute for Fisheries Research (RIVO), Centre for Shellfish Research (CSO), PO Box 77, 4400 AB Yerseke, The Netherlands.

E-mail: p.kamermans@ rivo.wag-ur.nl of the land-based groundwater system that causes a positive hydraulic head. Seepage from unconfined aquifers may occur at various locations, ranging from above the water line at low tide to as far as $14 \mathrm{~km}$ from the shore (Johannes 1980), and at depths of more than $30 \mathrm{~m}$ (Simmons 1992). The majority of the outflow, however, occurs close to the shore (Johannes 1980). The flux of groundwater into coastal waters can be substantial. By using the distribution of radium $\left({ }^{226} \mathrm{Ra}\right)$ as a tracer of freshwater input to nearshore waters of 
the South Atlantic Bight, Moore (1996) estimated that groundwater flow was of the order of $40 \%$ of the river flow to the bight.

The 2 main ecological effects of submarine groundwater discharge are a change in osmotic conditions and increased supply of nutrients to primary producers. In marine environments, groundwater outflow can reduce porewater salinity (Capone \& Bautista 1985, Simmons 1992, Matson 1993). Close contact with groundwater that percolates through the sediment is most likely in rooted vegetation in the coastal zone. Different salinity optima for growth and survival can have effects on the distribution of salt-marsh plants and mangrove trees (Smart \& Barko 1978, Clough 1992). As seagrass species also respond differently to salinity (McMillan \& Moseley 1967, Zieman 1975, Walker 1985, Walker \& McComb 1990, Bird et al. 1993, Adams et al. 1994, Hillman et al. 1995, Kamermans et al. 1999), their species diversity may be affected by differences in groundwater outflow. Continuous salinity reductions can result in the dominance of species that tolerate lower salinities. The discharged groundwater can be enriched with nutrients from natural organic matter, fertilisers, manure and septic tanks that leach into the groundwater on land (Johannes 1980, Capone \& Bautista 1985). The natural abundance of ${ }^{15} \mathrm{~N}$ in seagrass tissue can be used as a tracer of nitrogen inputs by groundwater (e.g. Fourqurean et al. 1997, McClelland \& Valiela 1998, Corbett et al. 1999). Enrichment of the heavier nitrogen isotope indicates denitrification, either in a suboxic zone or resulting from wastewater.

In tropical environments, coastal waters are usually oligotrophic. Under such conditions, groundwater can be a major source of nutrients. Several studies show the importance of groundwater in the nitrogen supply to tropical bays and lagoons (D'Elia et al. 1981, Lewis 1987, Lapointe et al. 1990, Dollar \& Atkinson 1992, Matson 1993). To sustain the freshwater demand, increasing amounts of groundwater are withdrawn in many places. Tack \& Polk (1999) developed a model of groundwater outflow along the Kenyan coast and showed that augmented groundwater depletion for domestic and agricultural use can lead to enhanced seawater intrusion. This can have profound effects on coastal ecosystems. For example, Tack \& Polk (1999) observed that the distribution pattern of mangrove forests along the Kenyan coast is closely related to groundwater outflow. Reductions in groundwater outflow rates are expected to endanger the mangroves, because absence of freshwater would expose the roots to higher salinity levels, leading to destruction of the forests.

In many tropical coastal zones, mangrove forests are bordered by seagrass meadows. This is also the case in East Africa. There, the coast is protected by a nearly continuous fringing reef which lies between 0.5 and $3 \mathrm{~km}$ offshore. The bottom of the back reef lagoons is composed of coral sand covered by vast seagrass meadows and occasional patches of hard coral. With its extensive root system, seagrass is a likely candidate for possible effects of changes in groundwater discharge. The limited exchange of coastal lagoons with the ocean makes these environments suitable for studying effects of groundwater discharge. It is unknown in what way the east African seagrass meadows are affected by groundwater outflow. Observations on possible relations between tropical seagrasses and groundwater are very scarce. To our knowledge, the only report in the literature is of Kohout \& Kolipinski (1967), who noted that Halodule wrightii Aschers. surrounded a submarine groundwater well, while the dominant species Thalassia testudinum Banks ex König was absent from these locations.

The objective of the present study is to relate the rate of coastal groundwater outwelling to the abundance and species diversity of lagoonal seagrasses in east Africa. Two models of groundwater outflow were used to select study sites with contrasting groundwater-outflow rates. For the dominant seagrass species, supplemental data on natural abundance of nitrogen isotopes in leaves were also collected.

\section{MATERIALS AND METHODS}

Groundwater models. MODFLOW96 (Harbaugh \& McDonald 1996) was used to construct 2 groundwater models: 1 for the Kenyan coastal region, between the Umba and Tana rivers, and 1 for the island of Zanzibar. MODFLOW96 is a modular 3-dimensional, finite difference groundwater flow model based on the following differential equation:

$$
\frac{\partial}{\partial x}\left(K_{x} \frac{\partial h}{\partial x}\right)+\frac{\partial}{\partial y}\left(K_{y} \frac{\partial h}{\partial y}\right)+\frac{\partial}{\partial z}\left(K_{z}\left(\frac{\partial h}{\partial z}\right)+N=Q\right)
$$

where $K$ is the hydraulic conductivity of the geological layer $\left(\mathrm{m} \mathrm{d}^{-1}\right), h$ is the piezometric head (m), $N$ is the net infiltration $\left(\mathrm{m} \mathrm{d}^{-1}\right)$, and $Q$ is the surface outflow $\left(\mathrm{m} \mathrm{d}^{-1}\right)$.

For practical reasons, the graphical user interface Visual MODFLOW produced by Waterloo Hydrogeologic was used.

The model domain for Kenya extends along the coastline, up to $25 \mathrm{~km}$ inland from the Tanzanian border (Umba River) to the Tana River and covers an area of about $8250 \mathrm{~km}^{2}$ in total; the cell size is 5 by $5 \mathrm{~km}$. Except for the topographical data, the conceptual model and the hydrogeological data used in this model are based on a former modelisation of the Athi-Tana catchment area (Tack \& Polk 1999). The phreatic hydrogeological layer is composed of permeable Ceno- 
zoic sediments $120 \mathrm{~m}$ thick, underlain by a silt-clay and/or grey clay aquitard with very low hydraulic conductivity $\left(6.56 \times 10^{-6}\right.$ to $\left.1.64 \times 10^{-5} \mathrm{~m} \mathrm{~d}^{-1}\right)$. This underlying layer was considered as a confining bed and thus represents the lower boundary of the model. The conductivity values of the Cenozoic sediments show spatial variation, thus 6 areas were defined with values ranging from 8.64 to $0.34 \mathrm{~m} \mathrm{~d}^{-1}$. Boundary conditions are obtained from the former larger and coarser modelisation of the Athi-Tana catchment area (Tack \& Polk 1999). Recharge values range from 50 to $75 \mathrm{~mm} \mathrm{yr}^{-1}$. For optimal precision of the groundwater model, detailed 1:50000 topographic maps (JICA 1991) were digitised. Tack \& Polk (1999) found a negative correlation between groundwater flow values and salinity measured in wells along the coast.

The model domain for Zanzibar includes the whole island and covers $1680 \mathrm{~km}^{2}$; the cell size is 2 by $2 \mathrm{~km}$. The geology of Zanzibar is composed of permeable Quaternary, Pliocene and Miocene sandy sediments, limestone and sandstone, underlain by an almost impermeable layer of Miocene clayey sands and sandy clays. The permeable layers belong to 1 single unconfined aquifer, which is divided into 5 regions with conductivity values ranging from 1.25 to $37.5 \mathrm{~m} \mathrm{~d}^{-1}$ (Colbert \& Wagner 1987). Recharge is estimated to be $30 \%$ of annual rainfall (Colbert \& Wagner 1987). Values range from 175 to $225 \mathrm{~mm} \mathrm{yr}^{-1}$. Topographic maps (scale 1:50000) (Department of Lands and Surveys Zanzibar 1985) were digitised for the whole island.

Flow rates $\left(\mathrm{m}^{2} \mathrm{~d}^{-1}\right)$ were calculated as the product between seepage flux $\left(\mathrm{m}^{3} \mathrm{~m}^{-2} \mathrm{~d}^{-1}\right)$ and aquifer thickness $(\mathrm{m})$. A sensitivity analysis was performed in order to evaluate the uncertainty of the model results. For this purpose, input values were increased and decreased by $20 \%$. Six of the most extreme results were selected for further statistical analysis.

Study area. Eight back-reef lagoons with different groundwater-outflow rates were selected in southern Kenya and on Zanzibar Island (Fig. 1). Sampling sites were chosen in function of the modelled amount of groundwater flow along the coastal strips of those areas. The mean outflow rates at the study sites were predicted to range from 17.9 to $0.4 \mathrm{~m}^{2} \mathrm{~d}^{-1}$. Seawater intrusion is likely to occur at locations where the model predicts groundwater flows $<1 \mathrm{~m}^{2} \mathrm{~d}^{-1}$ (Tack \& Polk 1999). All selected lagoons were situated on the east coast to ensure similar exposure to ocean swell and prevailing easterly winds. We expected effects of groundwater outflow to be largest for seagrass species which have rhizomes and roots extending deep into the sediment. In east Africa, a common species with deep roots is Thalassodendron ciliatum (Forsk.) Den Hartog (Den Hartog 1970, Duarte et al. 1998). Therefore, the study area was restricted to the zone in which $T$. ciliatum occurred.

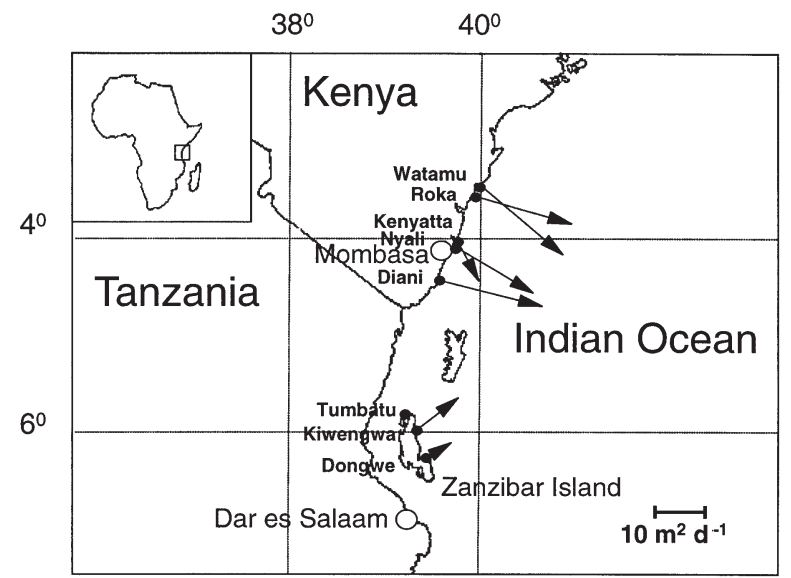

Fig. 1. Location of 8 sampling sites and groundwater flow as calculated by the model. Arrows show the direction of the groundwater flow and the lengths of the arrows represent the size of the flow (for values see Table 1, at Tumbatu the arrow is smaller than the location dot)

Sample collection and processing. For optimal underwater light conditions, fieldwork was conducted in the dry season. In March 1997, 5 lagoons along the southern part of the Kenyan coast were sampled and in February 1998 sampling was carried out in 3 lagoons on Zanzibar Island (Fig. 1). At each site, seagrass sampling was carried out along a $480 \mathrm{~m}$ transect. As depth may influence seagrass species composition, the transects were laid out parallel to the shore at the same depth (1.5 m below 0 Chart Datum). The distance to the beach varied from 100 to $500 \mathrm{~m}$. Samples were collected by SCUBA diving around low-water slack tide. Every $15 \mathrm{~m}$, a picture with a surface area of $1 \mathrm{~m}^{2}$, and in the same plane as the bottom, was taken with an underwater camera. Percentage coverage of the individual seagrass species and other components on the photographed plots was later estimated from the projected slides with an electronic area meter. All hard substrates (hard coral and rock), as well as organisms attached to hard substrates (benthic macro-algae and soft corals), were not included in the calculation of percentage seagrass coverage, i.e. the percentage of the available substrate that is covered by seagrass. Every $120 \mathrm{~m}$ along the transect, all aboveground material enclosed by a $0.06 \mathrm{~m}^{2}$ frame was harvested for biomass determination. Dry weight (DW) was determined per species after $2 \mathrm{~d}$ drying at $60^{\circ} \mathrm{C}$. The coverage data were used to calculate the Shannon (or ShannonWiener) diversity index (Shannon \& Weaver 1949):

$$
-\sum_{i=1}^{s}\left(p_{i}\right)\left(\log p_{i}\right)
$$

where $s$ is the total number of species and $p_{i}$ the proportion of the total seagrass coverage taken up by the 
ith species. The mean of the coverage data of all slides per transect was used to calculate the diversity index.

At the 5 spots per transect where biomass was sampled, sediment was collected by pushing a $50 \mathrm{ml}$ container $5 \mathrm{~cm}$ into the sediment. The samples were dried at $60^{\circ} \mathrm{C}$ prior to estimation of the sediment grain size with a particle sizer. Before grain-size analysis, pieces of shell and coral fragments $>1 \mathrm{~mm}$ were separated from the smaller fractions. At the 5 sampling spots per transect, porewater was collected over a depth of $10 \mathrm{~cm}$ with a $50 \mathrm{ml}$ syringe fitted with a $10 \mathrm{ml}$ modified pipette tip. Porewater salinity was determined with a conductivity meter. Atomic N:P ratios and $\delta^{15} \mathrm{~N}$ values of Thalassodendron ciliatum 3rd leaves were determined. Total phosphorus was determined spectrophotometrically using ammonium heptamolybdate as colouring reagent after microwave dissolution. Total nitrogen was measured with a $\mathrm{CN}$ element analyser. $\delta^{15} \mathrm{~N}$ values were measured with a isotope-ratio mass spectrometer coupled to a $\mathrm{CN}$ element analyser. The leaves were cut at the break point with the sheath, and cleaned with paper to remove epiphytes (Hemminga et al. 1995).
Statistical analysis. The significance of relationships of seagrass variables, porewater salinity and sediment characteristics, with groundwater outflow rates was determined using linear regression analyses (Sokal \& Rohlf 1995). To avoid pseudoreplication within a transect, regression lines were calculated from mean values per transect, instead of using the individual data obtained at each transect. As the assumptions of independence and normality could not be tested in this case, the non-parametric Kendall's coefficient of rank correlation $(\tau)$ was used to determine the significance of relationships between the data and groundwater outflow rates. A significance level of 0.05 was set in all tests. The statistical analyses were conducted using the STATISTICA programme StatSoft.

\section{RESULTS}

A total of 10 seagrass species were present at the study sites (Table 1). Total seagrass coverage and aboveground biomass did not show significant relationships with groundwater outflow (Table 1 ; coverage

Table 1. Groundwater outflow, porewater salinity $(\mathrm{n}=5$, except for Nyali and Dongwe where $\mathrm{n}=4$ ), seagrass coverage $($ Watamu: $\mathrm{n}=33$, Diani: $\mathrm{n}=33$, Roka: $\mathrm{n}=7$, Nyali: $\mathrm{n}=33$, Kiwengwa: $\mathrm{n}=30$, Kenyatta: $\mathrm{n}=33$, Dongwe: $\mathrm{n}=21$, Tumbatu: $\mathrm{n}=33$ ), aboveground biomass ( $\mathrm{n}=5$, except for Roka and Dongwe where $\mathrm{n}=2$ and 4, respectively), atomic N/P ratio Thalassodendron ciliatum leaves ( $\mathrm{n}=5$, except for except for Kenyatta and Roka where $\mathrm{n}=2$ and Tumbatu, Kiwengwa and Dongwe where $\mathrm{n}=3$ ), sediment median grain size, fraction $>1 \mathrm{~mm}$, and carbonate content $\left(\mathrm{n}=5\right.$ except for Dongwe where $\mathrm{n}=4$ ) in transect plots (mean with $\mathrm{SE}_{i}$ $\mathrm{K}=$ Kenya, $\mathrm{Z}=$ Zanzibar Island)

\begin{tabular}{|c|c|c|c|c|c|c|c|c|}
\hline Transect & $\begin{array}{l}\text { Watamu } \\
\quad(\mathrm{K})\end{array}$ & $\begin{array}{l}\text { Diani } \\
(\mathrm{K})\end{array}$ & $\begin{array}{l}\text { Roka } \\
(\mathrm{K})\end{array}$ & $\begin{array}{l}\text { Nyali } \\
(\mathrm{K})\end{array}$ & $\begin{array}{l}\text { Kiwengwa } \\
\text { (Z) }\end{array}$ & $\begin{array}{l}\text { Kenyatta } \\
(\mathrm{K})\end{array}$ & $\begin{array}{l}\text { Dongwe } \\
\text { (Z) }\end{array}$ & $\begin{array}{l}\text { Tumbatu } \\
\text { (Z) }\end{array}$ \\
\hline Outflow $\left(\mathrm{m}^{2} \mathrm{~d}^{-1}\right)$ & 17.9 & 15.8 & 15.0 & 12.8 & 10.2 & 6.1 & 2.0 & 0.4 \\
\hline Porewater salinity (psu) & $34.6(0.1)$ & $33.2(0.3)$ & $34.3(0.1)$ & $33.3(0.1)$ & $36.4(3.1)$ & $34.5(0.1)$ & $38.3(0.2)$ & $38.5(0.3)$ \\
\hline $\begin{array}{l}\text { Thalassodendron } \\
\text { ciliatum }(\%)\end{array}$ & $87.1(4.4)$ & $68.0(7.1)$ & $97.4(1.5)$ & $98.6(0.6)$ & $7.6(3.1)$ & $19.8(6.3)$ & $32.5(9.4)$ & $40.2(6.1)$ \\
\hline Thalassia hemprichii (\%) & & $4.2(2.8)$ & & & $21.1(3.1)$ & $7.6(3.7)$ & $15.4(3.8)$ & $16.3(2.5)$ \\
\hline Cymodocea serrulata (\%) & & $4.0(2.4)$ & & & & $51.7(7.2)$ & $1.0(1.0)$ & \\
\hline Cymodocea rotundata $(\%)$ & & & & & & $0.2(0.2)$ & $11.8(3.50)$ & \\
\hline Syringodium isoetifolium (\%) & & $7.1(3.3)$ & & & $0.4(0.3)$ & $0.7(0.5)$ & $8.1(1.9)$ & $4.1(1.8)$ \\
\hline Halodule uninervis (\%) & & $1.9(1.9)$ & & & $0.3(0.2)$ & $0.4(0.3)$ & $3.0(1.6)$ & $0.4(0.4)$ \\
\hline Halodule wrightii (\%) & & & & & $0.1(0.1)$ & $0.2(0.2)$ & & \\
\hline Halophila ovalis (\%) & & & & & & & & $0.4(0.2)$ \\
\hline Halophila stipulacea (\%) & & & & & $0.3(0.1)$ & $0.5(0.3)$ & $2.3(0.7)$ & $0.2(0.2)$ \\
\hline Enhalus acoroides (\%) & & & & & $1.8(1.2)$ & & & \\
\hline Total seagrass coverage (\%) & $87.1(4.4)$ & $85.2(4.1)$ & $97.4(1.5)$ & $98.6(0.6)$ & $31.6(5.2)$ & $81.1(3.8)$ & $74.1(5.9)$ & $61.6(4.1)$ \\
\hline 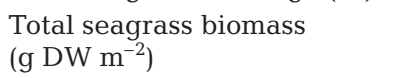 & $457(61)$ & $430(67)$ & $644(55)$ & $604(44)$ & $115(43)$ & $223(63)$ & $224(102)$ & $222(91)$ \\
\hline $\begin{array}{l}\text { Atomic N/P ratio } T \text {. } \\
\text { ciliatum leaves }\end{array}$ & $18.9(1.1)$ & $22.9(2.7)$ & $21.6(2.3)$ & $15.9(1.0)$ & $19.1(1.1)$ & $14.6(0.3)$ & $18.0(0.8)$ & $20.3(0.9)$ \\
\hline $\begin{array}{l}\text { Median grain size } \\
\text { sediment }(\mathrm{mm})\end{array}$ & $218(3)$ & $251(36)$ & $292(4)$ & $229(9)$ & $115(13)$ & $151(9)$ & $121(44)$ & $230(13)$ \\
\hline $\begin{array}{l}\text { Coarse fraction } \\
\text { sediment }(\%)\end{array}$ & $4.6(1.3)$ & $41.4(8.9)$ & $48.0(12.7)$ & $7.5(2.5)$ & $7.7(2.3)$ & $9.9(6.9)$ & $26.6(10.9)$ & $8.0(1.5)$ \\
\hline $\mathrm{CaCO}_{3}$ sediment (\%) & $35.1(2.2)$ & $47.8(9.3)$ & $89.0(1.1)$ & $8.5(2.3)$ & $90.3(0.6)$ & $61.0(10.0)$ & $84.0(1.5)$ & $91.1(0.9)$ \\
\hline
\end{tabular}




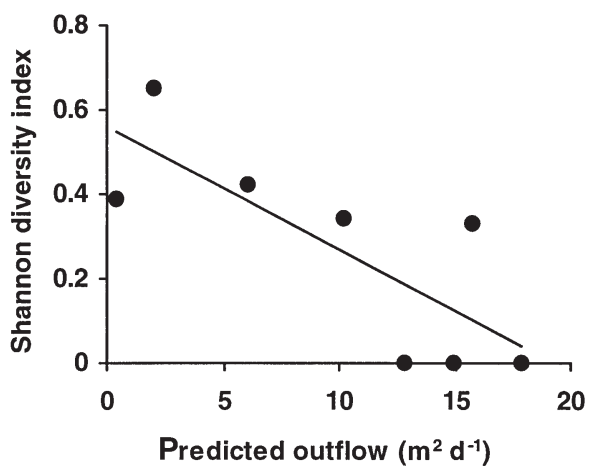

Fig. 2. Groundwater outflow as predicted by the model related to the Shannon diversity index per site $(n=1)$. Line of best fit is indicated, $\tau=-0.643, p=0.05$

$\tau=0.429, \mathrm{p}=0.20$, biomass $\tau=0.429, \mathrm{p}=0.20$ ). Thalassodendron ciliatum dominated the coverage at 6 sites. At 3 sites, it formed mono-specific meadows $>480 \mathrm{~m}$ long. The next most frequently observed species were Thalassia hemprichii (Ehrenb.) Aschers., Syringodium isoetifolium (Aschers.) Dandy, and Halodule uninervis (Forsk.) Aschers. The 3 species were found at the same 5 sites and $T$. hemprichii was the dominant species at 1 site. Cymodocea serrulata (R. Br.) Aschers. \& Magnus. occurred at 3 sites and had the highest coverage at 1 site (Kenyatta). Halophila stipulacea (Forsk.) Aschers. was recorded at 4 of the 8 sites, Halodule wrightii and Cymodocea rotundata Ehrenb. \& Hempr. ex Aschers. were found at 2 sites and Halophila ovalis (R. Br.) Hook. F. and Enhalus acoroides (L.f.) Royle only at 1 site. These latter 5 species all attained coverages $<10 \%$.

The sediment type showed some variation among sites. Median grain size of the sediment varied from ca. 100 to $300 \mathrm{~mm}$ and did not show a relation with groundwater outflow (Table $1 ; \tau=0.214, p=0.35$ ). Coarse sediments, with $>25 \%$ particles larger than $1 \mathrm{~mm}$, were found at 3 sites. These sites did not differ consistently from the other sites in terms of groundwater-outflow rate (Table $1 ; \tau=0.143, p=0.40$ ). Carbonate content of the sediment was generally high (at 5 sites $>60 \%$ ) and did not show a significant relation with groundwater-outflow rate (Table $1 ; \tau=-0.500$, $\mathrm{p}=0.15)$. Hence, sediment characteristics were independent of predicted groundwater-outflow rates. The atomic N/P ratio of Thalassodendron ciliatum leaves varied between 14.6 and 22.9, and did not show a significant relation with groundwater-outflow rate (Table $1 ; \tau=0.214, \mathrm{p}=0.35$ ).

Most sites with high groundwater outflow rates were located in Kenya while most sites with low outflow rates were situated on Zanzibar Island. These differences in outflow are expected as the size of the area

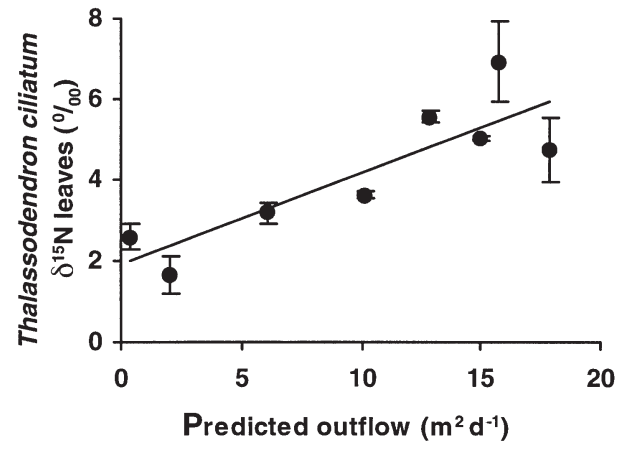

Fig. 3. $\delta^{15} \mathrm{~N}(\%)$ in Thalassodendron ciliatum leaves at the different sites (mean with $\mathrm{SE}_{;} \mathrm{n}=5$, except for Kenyatta and Roka where $\mathrm{n}=2$ and Tumbatu, Kiwengwa and Dongwe where $n=3$ ). Line of best fit is indicated, $\tau=0.643, p=0.05$

supplying the freshwater affects the outflow (Johannes 1980). Nevertheless, 1 of the lagoons in Kenya had a lower predicted groundwater outflow rate than 1 lagoon on Zanzibar Island (Fig. 1). Thus, low and high groundwater outflow sites occurred in both countries. None of the 10 seagrass species were restricted to either groundwater-outflow or non-outflow sites. Thus, the presence of a single species could not be considered indicative of the groundwater outflow conditions. However, Thalassodendron ciliatum was the only species occurring at 3 sites with high groundwater-outflow rates (Table 1). Low numbers of species were generally found in the presence of high groundwater outflow. Furthermore, the coverage was less evenly spread among species at those locations. This is indicated by a significant decrease in species diversity index with an increase in groundwater-outflow rate (Fig. 2). Apparently, not all seagrass species have the same tolerance for conditions caused by groundwater outflow.

Groundwater outflow commonly causes reduced porewater salinity and enhanced nitrogen supply. The present study showed lower porewater salinities at locations with higher groundwater-outflow rates, although this relation was not significant (Table $1 ; \tau=$ $-0.571, p=0.10$ ). Thalassodendron ciliatum leaves showed a significant increase in $\delta^{15} \mathrm{~N}$ with increased groundwater-outflow rates (Fig. 3). This suggests that, with increasing outflow rates, more plant-absorbed nitrogen is derived from groundwater.

The sensitivity analysis of the groundwater model resulted in 6 cases in which the order of the groundwater outflow at the sites showed some change. The results on seagrass diversity and nitrogen isotopic signature were related to the new groundwater values (Table 2). In general, the conclusions remain the same, a negative relation between groundwater outflow and seagrass diversity, and a positive relation between 
Table 2. The 6 most extreme changes in groundwater outflow rates $\left(\mathrm{m}^{2} \mathrm{~d}^{-1}\right)$ derived from the sensitivity analysis of the groundwater model. Kendall's coefficient of rank correlation $(\tau)$ with seagrass diversity and $\delta^{15} \mathrm{~N}$ values of Thalassodendron ciliatum leaves is presented in the bottom 2 rows

\begin{tabular}{|c|c|c|c|c|c|c|}
\hline Study site & $\begin{array}{l}\text { Outflow } \\
\text { in Case } 1\end{array}$ & $\begin{array}{l}\text { Outflow } \\
\text { in Case } 2\end{array}$ & $\begin{array}{l}\text { Outflow } \\
\text { in Case } 3\end{array}$ & $\begin{array}{l}\text { Outflow } \\
\text { in Case } 4\end{array}$ & $\begin{array}{l}\text { Outflow } \\
\text { in Case } 5\end{array}$ & $\begin{array}{l}\text { Outflow } \\
\text { in Case } 6\end{array}$ \\
\hline Watamu & 14.2 & 21.4 & 20.6 & 20.3 & 20.6 & 20.8 \\
\hline Diani & 12.6 & 18.9 & 15.9 & 15.4 & 15.4 & 15.4 \\
\hline Roka & 12.0 & 17.9 & 16.9 & 17.3 & 17.0 & 17.4 \\
\hline Nyali & 10.3 & 15.4 & 15.1 & 15.6 & 14.3 & 14.9 \\
\hline Kiwengwa & 11.3 & 11.3 & 11.3 & 11.3 & 11.3 & 11.3 \\
\hline Kenyatta & 4.9 & 7.3 & 7.1 & 7.4 & 6.9 & 7.1 \\
\hline Dongwe & 1.8 & 1.8 & 1.8 & 1.8 & 1.8 & 1.8 \\
\hline Tumbatu & 0.3 & 0.3 & 0.3 & 0.3 & 0.3 & 0.3 \\
\hline $\begin{array}{l}\text { Shannon } \\
\text { diversity } \\
\delta^{15} \mathrm{~N}\end{array}$ & $\begin{aligned} \tau & =-0.567 \\
p & =0.20 \\
\tau & =0.571 \\
p & =0.10\end{aligned}$ & $\begin{aligned} \tau & =-0.643 \\
p & =0.05 \\
\tau & =-0.643 \\
p & =0.05\end{aligned}$ & $\begin{aligned} \tau & =-0.718 \\
p & =0.02 \\
\tau & =0.571 \\
p & =0.10\end{aligned}$ & $\begin{aligned} \tau & =-0.794 \\
p & =0.01 \\
\tau & =0.500 \\
p & =0.20\end{aligned}$ & $\begin{aligned} \tau & =-0.718 \\
p & =0.02 \\
\tau & =0.571 \\
p & =0.10\end{aligned}$ & $\begin{aligned} \tau & =-0.718 \\
p & =0.02 \\
\tau & =0.571 \\
p & =0.10\end{aligned}$ \\
\hline
\end{tabular}

groundwater outflow and $\delta^{15} \mathrm{~N}$ values of Thalassodendron ciliatum leaves. In some cases the correlation was better than the original.

\section{DISCUSSION}

The present study suggest that groundwater outflow influences seagrass species diversity along the east African coast, with a low species diversity observed at lagoons with high predicted groundwater outflow. Sediment characteristics did not show a relation with predicted groundwater-outflow rates. Differences in sediment characteristics may thus be responsible for some of the unexplained variance in the observed relation between seagrass variables and groundwater-outflow. Sediment type affects nutrient availability and is known to influence plant productivity and community composition (Giesler et al. 1998). In addition, seagrass presence can influence sedimentation patterns (Fonseca 1989). The decline in species diversity with increasing outflow rate suggests a negative effect of groundwater outflow on growth and persistence of certain seagrass species. Porewater salinities were lower at locations where high groundwater-outflow rates were predicted by the model. The either direct or indirect influence of groundwater outflow is thus not restricted to mangrove forests on the intertidal shore as shown by Tack \& Polk (1999), but extends to permanently submerged rooted vegetation in the back-reef lagoons.

A candidate factor accounting for the negative influence of groundwater-outflow on seagrass diversity is reduced porewater salinity. A reduction in porewater salinity of up to 5 psu was found at high groundwateroutflow sites, although the single measurements around low tide during the dry season reported here do not give information on the variability between seasons. As part of our project, Kitheka (1999) measured salinity of groundwater at low tide in PVC tubes installed at the base of the beach of the groundwater outflow sites Nyali and Diani. Maximum salinity was around 23 psu in the rainy season and 26 psu in the dry season. These measurements show that porewater salinity was much lower close to the shore than in the lagoon, which is consistent with the observations from other locations (Johannes 1980). Furthermore, the difference in porewater salinity between the rainy and dry season is fairly small. The existence of a large storage capacity of the coastal aquifer and favourable recharge conditions cause groundwater to flow throughout the year (Kitheka 1999). Little information exists about the salinity tolerance of the 10 seagrass species encountered at the study sites. Knowledge on this tolerance and the distribution of the species in sites of different salinity indicate that Thalassia hemprichii, Cymodocea serrulata and Halophila ovalis dominate at locations with little groundwater outflow, while Cymodocea rotundata is expected to dominate at groundwater-outflow sites (Table 3). Indeed, $H$. ovalis was found at 3 sites with lower groundwater outflow. Moreover, $T$. hemprichii and C. serrulata attained high abundances at the 4 sites with low groundwater-outflow rates.

Cymodocea serrulata dominated at a site (Kenyatta) where the sediment structure suggested intense sand movements (N. Marbà pers. obs.). A related species, Cymodocea nodosa, showed fast vertical growth, and was thus able to survive burial by subaqueous migrating sand dunes in the Mediterranean (Marbà \& Duarte 1995). Similar fast growth of C. serrulata (cf. Vermaat et al. 1995) may explain the dominance of this species 
Table 3. Salinity tolerance of seagrass species. Source is indicated: (1) Den Hartog (1970), (2) Jagtap (1991), (3) Poiner et al. (1987), (4) Mitchell (1987), (5) Hillman et al. (1995), (6) Brouns \& Heijs (1985), (7) Aioi \& Pollard (1993), (8) Erftemeijer \& Herman (1994), (9) Kohout \& Kolipinski (1967)

\begin{tabular}{|lll|}
\hline Tolerant to low salinity & Tolerant to high salinity & No. specific tolerance reported \\
\hline Cymodocea rotundata (1) & Thalassia hemprichii $(2)$ & Thalassodendron ciliatum $(1,6)$ \\
Halodule wrightii (9) & Cymodocea serrulata $(1,2,3)$ & Syringodium isoetifolium $(6,7)$ \\
& Halodule wrightii $(4)$ & Halodule uninervis $(1)$ \\
& Halophila ovalis $(1,5)$ & Halodule stipulacea $(1)$ \\
& & Enhalus acoroides $(1,8)$ \\
\hline
\end{tabular}

over other, slower growing, species at Kenyatta. C. serrulata is capable of a much higher yearly rate of vertical elongation of the shoots $(13 \mathrm{~cm})$ compared to other species (e.g. Cymodocea rotundata $[1.5 \mathrm{~cm}]$, Halodule uninervis [4 cm], Syringodium isoetifolium [9 $\mathrm{cm}$ ] and Thalassia hemprichii [3 cm]) (Vermaat et al. 1995). C. rotundata was not particularly abundant at high groundwater-outflow sites, unlike as was expected (Table 3).

Carbonate-rich sediments often have low porewater phosphate concentrations. In such cases, seagrasses are more likely to be limited by phosphorus rather than nitrogen (Fourqurean et al. 1992). Phosphorus concentrations in the porewater were not determined in the present study. However, the atomic N:P ratio of Thalassodendron ciliatum leaves was determined, and varied between 14.6 and 22.9. These values are lower than values of 20 to 100 as reported by Fourqurean et al. (1992) for Thalassia testudinum in carbonate sediments in Florida Bay. At this location, the authors concluded that the seagrass was P-limited. The median grain size of the sediment at our study sites is comparable to the carbonate sediments in Indonesia where Erftemeijer \& Middelburg (1993) determined nutrient concentrations of the porewater and atomic N:P ratios of seagrass parts. They concluded that seagrass was not P-limited in those carbonate sediments, possibly as a result of lower sorptive capacity of the sediment caused by a smaller surface area. Thus, it seems likely that, at our study sites in east Africa, T. ciliatum is not P-limited.

In the framework of our project, Mwashote et al. (1999) determined the nitrogen concentration in the water column at 3 of the study sites (Nyali, Diani and Kenyatta). In general, the nitrate and nitrite levels for the low groundwater outflow site Kenyatta were much lower than for the high groundwater outflow sites Diani and Nyali (1.5 vs $10 \mu \mathrm{M})$. This suggests that nitrogen is supplied via groundwater to the back-reef lagoons. The nitrogen-stable isotope signatures of Thalassodendron ciliatum indicate that groundwater is important as a source of nitrogen. It is not known what the $\delta^{15} \mathrm{~N}$ signature of $T$. ciliatum should be when plants use groundwater. However, some information for other seagrass species is available. McClelland \& Valiela (1998) measured $\delta^{15} \mathrm{~N}$ in groundwater (10\%) and in Zostera marina $(6 \%)$. And Corbett et al. (1999) found values of 11 to $13 \%$ in Thalassia testudinum in an area subjected to groundwater outflow in Florida Bay. These values are comparable to the maximum values of 7 to $10 \%$ o that we observed for $T$. ciliatum.

The reduction in porewater salinity at groundwater outflow sites is relatively low, which makes it unlikely that a difference in optimum salinity for growth is the main factor causing reduced diversity at these sites. Differences in nitrogen supply may be a more likely candidate to explain the observed pattern in species diversity and abundance. A possible mechanism could be differences in competition for porewater nitrogen between species. To establish a substantive link between the observed reduced seagrass diversity or enhanced $\delta^{15} \mathrm{~N}$ values of Thalassodendron ciliatum leaves on the one hand and increased groundwater outflow rates on the other, further exploration through detailed measurements of groundwater outflow rates and groundwater nitrogen isotopic composition is needed.

Acknowledgements. We are grateful to the staff of the Kenyan Marine and Fisheries Research Institute in Mombasa, the Kenya Wildlife Service in Mombasa and Watamu, and the Institute of Marine Sciences in Zanzibar Town for providing service and facilities. Several private land owners are thanked for allowing us to make use of their beach access. We thank Joop Nieuwenhuize, Yvonne Maas and Peter van Breugel for taking care of the nutrient analyses. Thanks are due to Pim van Avesaath and 3 anonymous reviewers for critically reading an earlier draft of the manuscript. This research is part of the GROFLO project which was supported by grant no. IC18-CT96-0065 of the Commission of the European Communities within the framework of the INCO Programme. This is NIOO-CEMO publication no. 2854.

\section{LITERATURE CITED}

Adams JB, Knoop WT, Bate GC (1994) The distribution of estuarine macrophytes in relation to freshwater. Bot Mar $35: 215-226$ 
Aioi K, Pollard PC (1993) Biomass, leaf growth and loss rate of the seagrass Syringodium isoetifolium on Dravuni Island, Fiji. Aquat Bot 46:283-292

Bird KT, Cody BR, Jewett-Smith J, Kane ME (1993) Salinity effects on Ruppia maritima L. cultured in vitro. Bot Mar 36: 23-28

Brouns JJWM, Heijs FML (1985) Tropical seagrass ecosystems in Papua New Guinea. A general account of the environment, marine flora and fauna. Proc K Ned Akad Wet C88:145-182

Capone DG, Bautista MF (1985) A groundwater source of nitrate in nearshore marine sediments. Nature 313:214-216

Clough BF (1992) Primary productivity and growth of mangrove forests. Coast Estuar Stud 41:225-250

Colbert G, Wagner BH (1987) Hydrogeological map of Zanzibar (map no. 3344). Department of Conference Services, United Nations, New York

Corbett DR, Chanton J, Burnett W, Dillon K, Rutkowski C, Fourqurean JW (1999) Patterns of groundwater discharge into Florida Bay. Limnol Oceanogr 44:1045-1055

D'Elia CF, Webb KL, Porter JW (1981) Nitrate-rich groundwater inputs to Discovery Bay, Jamaica: a significant source of N to local reefs? Bull Mar Sci 31:903-910

Den Hartog C (1970) The seagrasses of the world. North Holland Publishers, Amsterdam, p 275

Department of Lands and Surveys Zanzibar (DLSZ) (1985) Topographic maps of Zanzibar. Series Y742, edn I-OSD. Government of the United Kingdom, London

Dollar SJ, Atkinson MJ (1992) Effects of nutrient subsidies from groundwater to nearshore marine ecosystems off the island of Hawaii. Estuar Coast Shelf Sci 35:409-424

Duarte CM, Merinio M, Agawin NSR, Uri J, Fortes MD, Gallegos ME, Marbà N, Hemminga MA (1998) Root production and belowground seagrass biomass. Mar Ecol Prog Ser 171:97-108

Erftemeijer PLA, Herman PMJ (1994) Seasonal changes in environmental variables, biomass, production and nutrient contents in two contrasting tropical intertidal seagrass beds in south Sulawesi (Indonesia). Oecologia 99:45-59

Erftemeijer PLA, Middelburg JJ (1993) Sediment-nutrient interactions in tropical seagrass beds: a comparison between a terrigenous and a carbonate sedimentary environment in South Sulawesi (Indonesia). Mar Ecol Prog Ser 102:187-198

Fonseca MS (1989) Sediment stabilization by Halophila decipiens in comparison to other seagrasses. Estuar Coast Shelf Sci 29:501-507

Fourqurean JW, Zieman JC, Powell GVN (1992) Relationships between porewater nutrients and seagrasses in a subtropical carbonate environment. Mar Biol 114:57-65

Fourqurean JW, Moore TO, Fry B, Hollibaugh J (1997) Spatial and temporal variation in $\mathrm{C}: \mathrm{N}: \mathrm{P}$ ratios, $\delta^{15} \mathrm{~N}$, and $\delta^{13} \mathrm{C}$ of eelgrass Zostera marina as indicators of ecosystem processes, Tomales Bay, California, USA. Mar Ecol Prog Ser 157:147-157

Giesler R, Högberg M, Högberg P (1998) Soil chemistry and plants in fennoscandian boreal forest as exemplified by a local gradient. Ecology 79:119-137

Harbaugh AW, McDonald MG (1996) User's documentation for MODFLOW-96, an update to the US Geological Survey Modular Finite-Difference Ground-Water Flow Model. US Geological Survey, Reston, VA, Open-file rep 96-485

Hemminga MA, Gwada P, Slim FJ, de Koeyer P, Kazungu J (1995) Leaf production and nutrient contents of the seagrass Thalassodendron ciliatum in the proximity of a mangrove forest (Gazi Bay, Kenya). Aquat Bot 50:159-170

Hillman K, McComb AJ, Walker DI (1995) The distribution and primary production of the seagrass Halophila ovalis in the Swan/Canning estuary, western Australia. Aquat Bot 51:1-54

Jagtap TG (1991) Distribution of seagrasses along the Indian coast. Aquat Bot 40:379-386

JICA (Japan International Cooperation Agency) (1991) Topographic maps of Kenya. Series Y731, edn 4-JICA. Kenya Government, Nairobi

Johannes RE (1980) The ecological significance of the submarine discharge of groundwater. Mar Ecol Prog Ser 3:365-373

Kamermans P, Hemminga MA, de Jong DJ (1999) The significance of salinity and silicon levels for growth of a formerly estuarine eelgrass (Zostera marina L.) population (Lake Grevelingen, The Netherlands). Mar Biol 133:527-539

Kitheka JU (1999) Groundwater outflow dynamics and circulation at Diani and Nyali mesotidal beaches in Kenya. In: Hemminga MA (ed) Anthropogenically induced changes in groundwater outflow and quality, and the functioning of eastern African nearshore ecosystems (GROFLO). Final Report of the INCO Project Part 2, Netherlands Institute of Ecology, Centre for Estuarine and Coastal Ecology, Yerseke, p 5-30

Kohout FA, Kolipinski MC (1967) Biological zonation related to groundwater discharge along the shore of Biscayne Bay, Miami, Florida. In: G Lauff (ed) Estuaries. AAAS Publ. No. 83, p 488-499

Lewis JB (1987) Measurements of groundwater seepage flux onto a coral reef: spatial and temporal variations. Limnol Oceanogr 32:1165-1169

Marbà N, Duarte CM (1995) Coupling of seagrass (Cymodocea nodosa) patch dynamics to subaqueous dune migration. J Ecol 83:381-389

Matson EA (1993) Nutrient flux through soils and aquifers to the coastal zone of Guam (Mariana Islands). Limnol Oceanogr 38:361-371

McClelland JW, Valiela I (1998) Linking nitrogen in estuarine producers to land-derived sources. Limnol Oceanogr 43:577-585

McMillan C, Moseley FN (1967) Salinity tolerances of five marine spermatophytes of Redfish Bay, Texas. Ecology: 48:503-506

Mitchell CA (1987) Growth of Halodule wrightii in culture and the effects of cropping, light, salinity and atrazine. Aquat Bot 28:25-37

Moore WS (1996) Large groundwater inputs to coastal waters revealed by ${ }^{226} \mathrm{Ra}$ enrichments. Nature 380:612-614

Mwashote BM, Mwangi SN, Kazungu JM (1999) Groundwaterassociated anthropogenic influence on coastal lagoons: Diani and Nyali Beach, Kenya. In: Hemminga MA (ed) Anthropogenically induced changes in groundwater outflow and quality, and the functioning of eastern African nearshore ecosystems (GROFLO). Final Report of the INCO Project Part 2, Netherlands Institute of Ecology, Centre for Estuarine and Coastal Ecology, Yerseke, p 31-45

Poiner IR, Stapels DJ, Kenyon R (1987) Seagrass communities of the Gulf of Carpentaria, Australia. Aust J Mar Freshw Res 38:121-131

Shannon CE, Weaver W (1949) The mathematical theory of communication. University of Illinois Press, Urbana, p 117

Simmons GM (1992) Importance of submarine groundwater discharge (SGWD) and seawater cycling to material flux across sediment/water interfaces in marine environments. Mar Ecol Prog Ser 84:173-184

Smart RM, Barko JW (1978) Influence of sediment salinity and nutrients on the physiological ecology of selected salt marsh plants. Estuar Coast Mar Sci 7:487-495

Sokal RR, Rohlf FJ (1995) Biometry 3rd edn. WH Freeman, New York, p 887 
Tack J, Polk P (1999) The influence of tropical catchments upon the coastal zone: modelling the links between groundwater and mangrove losses in Kenya, India/ Bangladesh and Florida. In: Harper D, Brown T (eds) The sustainable management of tropical catchments. John Wiley and Sons, London, p 359-371

Vermaat JE, Agawin NSR, Duarte CM, Fortes MD, Marbà N, Uri JS (1995) Meadow maintenance, growth and productivity of a mixed Philippine seagrass bed. Mar Ecol Prog Ser 124:215-225

Editorial responsibility: Otto Kinne (Editor),

Oldendorf/Luhe, Germany
Walker DI (1985) Correlations between salinity and growth of the seagrass Amphibolis antarctica (Labill.) Sonder \& Aschers., in Shark Bay, western Australia, using a new method for measuring production rate. Aquat Bot 23:13-26

Walker DI, McComb AJ (1990) Salinity response of the seagrass Amphibolis antarctica (Labill.) Sonder et Aschers.: an experimental validation of field results. Aquat Bot 36:359-366

Zieman JC (1975) Seasonal variation of turtle grass, Thalassia testidunum König, with reference to temperature and salinity effects. Aquat Bot 1:107-123

Submitted: July 21, 2000; Accepted: October 25, 2001

Proofs received from author(s): March 22, 2002 